\title{
Accounting
}

\section{Factors affecting the management capacity of business leaders}

\author{
Thanh Thuy $\mathrm{Cu}^{\mathrm{a}^{*}}$
}

${ }^{a}$ Hanoi Architectural University, Vietnam

\begin{tabular}{l}
\hline C H R O N I C L E \\
\hline Article history: \\
Received March 182020 \\
Received in revised format May \\
262020 \\
Accepted July 182020 \\
Available online \\
July 182020 \\
\hline Keywords: \\
Management capability \\
Leader \\
Vietnam
\end{tabular}

\section{A B S T R A C T}

This study was designed to identify factors affecting management capacity of business leaders, and identified factors such as macro-environmental factors, internal factors, knowledge of business leaders and traditional family result factors, as well as skills of business leaders. These factors have different levels of effects on the management capacity of business leaders. The findings are the basis for proposing recommendations to more enhance the management capacity of business leaders. Data for the study was collected from a survey of business leaders in Bac Ninh province, exploratory factor analysis (EFA) and multivariate regression was used for analysis in this study.

\section{Introduction}

Enterprises have an important position and role in the socio-economic development not only for countries but also for localities, good production and business results of the enterprise will create many jobs for workers, promote innovation in the business itself, contribute to the state budget, etc. In facts, enterprises in Bac Ninh province also show the role of promoting socioeconomic development of the locality. Specifically, by the end of 2018, the total number of enterprises operating in Bac Ninh province was 7471 ones, pre-tax profits of the enterprises in 2018 reached about 93.6 VND trillion and a monthly average income of workers reached about 9.7 VND million. It shows that enterprises not only contributed significantly to their operations but also contribute to the community, promote local and national economic development. However, besides the achieved results, there are still companies facing difficulties due to failure to meet the competition requirements in the context of Vietnam's integration has become increasingly deep and wide, which has led to the suspension of operations, the cause of these phenomena are due to the weak management capacity of business leaders, while labor quality does not meet requirements, product quality does not meet a market demand, etc. and businesses do not meet the requirement to perform actively. This study was carried to study the management capacity of business leaders in Bac Ninh province, specifically analyzing the factors affecting the management capacity of business leaders in Bac Ninh province, on that basis, the study will determine the factors influence the management capacity of business leaders in Bac Ninh province. The research findings are considered as the basis for proposing recommendations to improve the management capacity for business leaders in Bac Ninh province. From that, it can contribute to the development of enterprises in the province 


\section{Research overview}

The management capabilities of business leaders have been studied in different scopes with different specific fields. Mira et al. (2019) highlighted some important functions that create core values of the enterprise such as human resources for corporate governance. Human resources for corporate governance determine the success or failure of an enterprise and the reputation of the brand. While, Cohen and Levinthal (2000), Barringer and Jones (2004), Barringer et al. (2005) discussed the relationship between business management capacity, training and innovation, the relationship between developing enterprise management capacity and training and innovation, as well as the relationship between developing management capacity and enterprise growth. Using the theoretical framework of Mintzberg $(1973,2009)$ as a theoretical basis in his research, de Oliveira et al. (2015) studied the management capacity of the directors of enterprises in two ways according to management function and management role. For a functional management approach, management capacity is constituted by four items: Planning, leadership, organization and control.

Pham (2020) examined the effect of human resource management practices on enterprises' competitive advantages and business performance for the case of Vietnam Post and Telecommunications Group enterprises. They reported that: (1) Functional activities of human resource management, leading and encouraging changes, team and group activities, employee involvement, administrative activities were positively associated with human resource management practices at Vietnam Post and Telecommunications Group enterprises. Vuong and Sid (2020) studied the effect of human resource management practices on employee engagement and moderating role of gender and marital status in Vietnamese banking industry. Khuong et al. (2020) studied the effects of human resource management practices on employees' motivation and loyalty. Alzgool (2019) tried to understand the nexus between Green human resources management, green management towards describing individual green values. The survey also examined the moderation of green management on the relationship between Green human resources management and individual green values. The results of the structural equation modelling from the non-managerial employees of the company highlighted a significant positive relationship between green human resources management and individual green values. The study also indicated significant relationship between green management and enhancement of individual green values.

\section{Research Methods}

\subsection{Data collection method}

For the secondary data: Data for research is collected from published documents, i.e, the statistical yearbook of Bac Ninh province related to enterprises.

For the primary data:

+ Primary data including survey data we have collected them through a standardized survey table with the leaders of enterprises are operating in the Bac Ninh province.

+ The size of the sample applied in this study is based on the requirements of factor analysis and multivariate regression: For factor analysis: Based on the study of Hair et al. $(2006,2011)$, the minimum sample size is 5 times the total observed variables. For multivariate regression analysis, the minimum sample size to achieve is calculated using the formula: $50+8 \times \mathrm{m}$ (m: number of independent variables) (Tabachnick \& Fidell, 1996). Accordingly, the minimum sample size guaranteed for the study is 266 observations. The research team issued 625 questionnaires to enterprises in different fields, the survey sample structure is scaled according to the overall sample by type of enterprise. After that, the author collected 513 questionnaires, with this survey, the author made data entry into the Excel software and removed questionnaires which did not meet the information requirements due to a lack of information. We were lefts with 456 observations which met the minimum sample size condition to be able to perform statistical calculations.

\subsection{Data analysis method}

Exploratory Factor Analysis (EFA) and multivariate regression methods were selected to analyze data in the study.

\section{Expected variables of the study}

We first present the results of our investigation on variables used for the survey. Table 1 presents details of the variables used for the survey along with the code and references. 
Table 1

Variables used in the study

\begin{tabular}{|c|c|c|c|}
\hline Variable name & The scale & Code & $\begin{array}{l}\text { Bases for } \\
\text { selecting } \\
\text { variables }\end{array}$ \\
\hline \multicolumn{4}{|c|}{ The Dependent variable } \\
\hline $\begin{array}{l}\text { Management capability } \\
\text { of business leaders } \\
\text { (NLQL) }\end{array}$ & $\begin{array}{l}\text { + Management capacity in the planning process } \\
\text { + Management capacity in the organization process } \\
\text { + Management capacity in the leadership process } \\
\text { + Management capacity in control process }\end{array}$ & $\begin{array}{l}\text { NLQL1 } \\
\text { NLQL2 } \\
\text { NLQL3 } \\
\text { NLQL4 }\end{array}$ & $\begin{array}{l}\text { de Oliveira et al. } \\
(2015)\end{array}$ \\
\hline \multicolumn{4}{|c|}{ The Independent variable } \\
\hline $\begin{array}{l}\text { Factors belong to self and } \\
\text { their family of business } \\
\text { leaders (BT) }\end{array}$ & $\begin{array}{l}\text { + Professional knowledge about the field of business } \\
\text { + Business leaders are a passion for work. } \\
\text { + Business leaders have a good ability to use informatics and foreign languages } \\
\text { + Business leaders are aware of learning and practicing to improve their professional skills } \\
\text { + Business leaders are responsible for work } \\
\text { + Business leaders can react quickly to jobs } \\
\text { + Business leaders have work-solving skills } \\
\text { + Business leaders have the nature and talent } \\
\text { + Business leaders have good health to ensure their jobs } \\
\text { + Family has a tradition in the field of business } \\
\text { + Family culture of business leaders }\end{array}$ & $\begin{array}{l}\text { BT1 } \\
\text { BT2 } \\
\text { BT3 } \\
\text { BT4 } \\
\text { BT5 } \\
\text { BT6 } \\
\text { BT7 } \\
\text { BT8 } \\
\text { BT9 } \\
\text { BT10 } \\
\text { BT11 }\end{array}$ & $\begin{array}{l}\text { Mintzberg } \\
\text { (2009), Cohen \& } \\
\text { Levinthal (2000) }\end{array}$ \\
\hline $\begin{array}{l}\text { Internal factors of } \\
\text { enterprise (DN) }\end{array}$ & $\begin{array}{l}\text { + The diversity of business lines of the enterprises } \\
+ \text { Culture of the enterprises } \\
\text { + Features of the development phases of the enterprises } \\
\text { + Resources of the enterprises } \\
\text { + Human resource development policies of enterprises } \\
\text { + Reward mechanism and disciplinary sanctions of enterprises } \\
\text { + Policies for training and retraining employees in the company }\end{array}$ & $\begin{array}{l}\text { DN1 } \\
\text { DN2 } \\
\text { DN3 } \\
\text { DN4 } \\
\text { DN5 } \\
\text { DN6 } \\
\text { DN7 }\end{array}$ & $\begin{array}{l}\text { Mintzberg } \\
\text { (2009), Cohen \& } \\
\text { Levinthal (2000) }\end{array}$ \\
\hline $\begin{array}{l}\text { Macro environmental } \\
\text { factors } \\
\text { (VM) }\end{array}$ & $\begin{array}{l}\text { + Local socio-economic development strategy } \\
\text { + Local socio-economic conditions } \\
\text { + International economic integration } \\
\text { + The competition of enterprises in the same field } \\
\text { + Policy to support enterprise development of the local } \\
\text { + Career development planning of the locality }\end{array}$ & $\begin{array}{l}\text { VM1 } \\
\text { VM2 } \\
\text { VM3 } \\
\text { VM4 } \\
\text { VM5 } \\
\text { VM6 }\end{array}$ & $\begin{array}{l}\text { Mintzberg } \\
\text { (2009), Cohen \& } \\
\text { Levinthal (2000) }\end{array}$ \\
\hline
\end{tabular}

\section{Findings}

Source: Compiled by author

\subsection{The result of enterprises development in Bac Ninh province}

From 2016 to 2018, the scale of enterprises operating in production and business according to the types of enterprise in Bac Ninh province tends to increase, as follows:

\section{Table 2}

The scale of enterprises by types of enterpris (Unit: Enterprise)

\begin{tabular}{|c|c|c|c|}
\hline Years & 2016 & 2017 & 2018 \\
\hline The total & 5320 & 6980 & 7471 \\
\hline 1. State-owned enterprises & 18 & 16 & 16 \\
\hline 1.1. Central & 12 & 10 & 10 \\
\hline 1.2. Local & 6 & 6 & 6 \\
\hline 2. Non-state enterprises & 4642 & 6084 & 6375 \\
\hline 2.1. Private & 269 & 261 & 273 \\
\hline 2.2. Limited liability company & 3663 & 4907 & 5145 \\
\hline 2.3. Joint-stock company & 9 & 9 & 9 \\
\hline 3. Foreign-invested enterprises & 660 & 880 & 1080 \\
\hline 3.1. Enterprises with $100 \%$ foreign investment & 635 & 854 & 1052 \\
\hline 3.2. Venture enterprises & 25 & 26 & 28 \\
\hline
\end{tabular}

Source: Statistical yearbook of Bac Ninh province

According to Table 2, enterprises operating in Bac Ninh province by the end of 2018 were mainly non-state enterprises, in 2016, non-state enterprises consisted of 4642 units accounted for $87.63 \%$ of the total number of enterprises operating in the province, this number tends to increase and reached 6375 enterprises in 2018 regarding absolute numbers, however, the proportion of enterprises tended to decrease, accounting for $85.3 \%$ of the total number of enterprises in the province. The non-state enterprises operating in Bac Ninh province are mainly a group of limited liability companies, accounted for $68.9 \%$ of total enterprises in Bac Ninh province in 2018. For the type of enterprise with foreign investment, these enterprises include venture enterprises and 
enterprises with $100 \%$ foreign capital, with these two types, enterprises with $100 \%$ foreign capital account for a relatively large proportion and tended to increase during the research period. In 2016, enterprises with 100\% foreign capital accounted for $11.9 \%$ of the total number of enterprises operating in Bac Ninh province (out of $12.4 \%$ of enterprises with foreign investment) and this number tends to increase when in 2018 reached $14.1 \%$ of the total number of enterprises operating in Bac Ninh province.

Table 3

$\underline{\text { Scale of employees working in enterprises in Bac Ninh province (Unit: People) }}$

\begin{tabular}{|c|c|c|c|}
\hline Years & 2016 & 2017 & 2018 \\
\hline The total & 331650 & 400852 & 411826 \\
\hline 1. State-owned enterprises & 8575 & 5618 & 5850 \\
\hline 1.1. Central & 6663 & 3909 & 4070 \\
\hline 1.2. Local & 1912 & 1709 & 1780 \\
\hline 2. Non-state enterprises & 110200 & 118516 & 124442 \\
\hline 2.1. Private & 2862 & 2624 & 2755 \\
\hline 2.2. Limited liability company & 76214 & 82428 & 86550 \\
\hline 2.3. Joint-stock company & 3188 & 3264 & 3427 \\
\hline 2.4. Joint-stock companies without capital of State & 27972 & 30200 & 31710 \\
\hline 3. Foreign-invested enterprises & 212875 & 276718 & 281534 \\
\hline 3.1. Enterprises with $100 \%$ foreign investment & 209141 & 273076 & 277829 \\
\hline 3.2. Venture enterprises & 3734 & 3642 & 3705 \\
\hline
\end{tabular}

The scale of labor working in enterprises in Bac Ninh province tends to increase in the period 2016-2018, in 2016, the total number of employees working in enterprises in Bac Ninh province is 331650 employees, this number increased to 411826 in 2018. This shows the extremely important position of enterprises in creating jobs for workers in Bac Ninh province. Among enterprises that have a position and role in attracting the workforce, foreign-invested enterprises account for the largest proportion, accounting for $68.4 \%$ of the total number of employees working in enterprises in Bac Ninh province, followed by non-state enterprises that created jobs for about $30.2 \%$ of the total number of employees working in enterprises. Net turnover for production and business activities of enterprises in Bac Ninh province increased in the period 2016-2018, in 2016, net revenue reached VND 831152 billion and this figure increased to VND 1399320 billion in 2018. For state-owned enterprises, net profits decreased during the research period, in 2016, net revenue for state-owned enterprises was about VND 13080 billion, then decreased to VND 4672 billion in 2018.

Table 4

Net turnover of production and business activities of enterprises in Bac Ninh province (Unit: VND billion)

\begin{tabular}{|c|c|c|c|}
\hline Years & 2016 & 2017 & 2018 \\
\hline The total & 831152 & 1187298 & 1399320 \\
\hline 1. State-owned enterprises & 13080 & 3737 & 4672 \\
\hline 1.1. Central & 12454 & 3281 & 4102 \\
\hline 1.2. Local & 626 & 456 & 570 \\
\hline 2. Non-state enterprises & 124272 & 169798 & 183432 \\
\hline 2.1. Private & 6549 & 5768 & 6230 \\
\hline 2.2. Limited Liability Company & 82288 & 117601 & 127059 \\
\hline 2.3. Joint-stock companies with capital of State & 6662 & 1457 & 1573 \\
\hline 2.4. Joint-stock companies without capital of State & 28773 & 44972 & 48570 \\
\hline 3. Foreign-invested enterprises & 693800 & 1013762 & 1211216 \\
\hline 3.1. Enterprise with $100 \%$ foreign capital & 679088 & 1008179 & 1203628 \\
\hline 3.2. Venture enterprises & 14712 & 5584 & 7588 \\
\hline
\end{tabular}

For non-state enterprises and foreign enterprises, net turnover tends to increase during the research period, in 2016, net revenue for non-state enterprises reached 124272 billion VND, this figure increased to 183432 billion VND in 2018. For foreign enterprises, the increase in net profits is much stronger, in 2016, net revenue was VND 693800 billion, this figure increased to VND 1211216 billion in 2018. Of the total net revenue of enterprises operating in Bac Ninh province, the net revenue from foreign enterprises accounted for a large proportion, in 2018, the proportion of the net income of enterprises accounted for about $68.4 \%$ of the total net revenue of enterprises operating in Bac Ninh province. In 2016, enterprises contributed 12417 billion VND to the state budget, this figure increased to 13588 billion VND in 2018. State budget contribution was largely contributed by non-state enterprises and foreign-invested enterprises are given in Table 5. The contribution to the state budget of foreigninvested enterprises in 2016 reached VND 9325 billion, this figure increased to VND 9714 billion in 2018. In particular, enterprises with $100 \%$ foreign capital account for more than $90 \%$ of the contribution to the state budget for this group of enterprises. The above analysis results show that, although there are specific results for the development of enterprises, however, enterprises have not yet fully realized their available potentials to have better results in production and business activities and there are still cases where companies have to stop operating, manufacturers have inefficient business results. 
Table 5

Taxes and amounts payable to the state budget (Unit: VND billion)

\begin{tabular}{|c|c|c|c|}
\hline Years & 2016 & 2017 & 2018 \\
\hline The total & 12417 & 12571 & 13588 \\
\hline 1. State-owned enterprises & 574 & 353 & 391 \\
\hline 1.1. Central & 546 & 330 & 363 \\
\hline 1.2. Local & 28 & 23 & 28 \\
\hline 2. Non-state enterprises & 2518 & 3224 & 3483 \\
\hline 2.1. Private & 34 & 69 & 75 \\
\hline 2.2. Limited Liability Company & 1522 & 1709 & 1846 \\
\hline 2.3. Joint-stock companies with capital of State & 39 & 58 & 63 \\
\hline 2.4. Joint-stock companies without capital of State & 923 & 1388 & 1499 \\
\hline 3. Foreign-invested enterprises & 9325 & 8994 & 9714 \\
\hline 3.1. Enterprise with $100 \%$ foreign capital & 8916 & 8836 & 9549 \\
\hline 3.2. Venture enterprises & 409 & 158 & 165 \\
\hline
\end{tabular}

Source: Statistical yearbook of Bac Ninh province

\subsubsection{Analysis of factors affecting the management capacity of business leaders}

With the collected data, the author carried a reliability test of the data using Cronbach's alpha, the results showed that the collected data met the requirements. The author then conveyed an EFA analysis of the factors affecting the management capacity of business leaders. The author checked whether the data are full conditions for analysis by KMO and Bartlett's tests or not, the specific results are as follows:

Table 6

KMO and Bartlett's Test

KMO and Bartlett's Test

Kaiser-Meyer-Olkin Measure of Sampling Adequacy.

\begin{tabular}{ll} 
& .756 \\
Approx. Chi-Square & 12192.378 \\
Df & 276 \\
Sig. & .000 \\
\hline
\end{tabular}

Source: Analysis results from the author's research data.

KMO and Bartlett's test results in Table 6 show that this data is perfectly suitable for performing factor analysis with KMO test value $=0.756$ is statistically significant at the $1 \%$ level $(\mathrm{Sig} .=0.000<0.005)$, so the research model is suitable. Then, the author performed the analysis of variance extracted of factors:

Table 7

Testing variance extracted of factors

\begin{tabular}{|c|c|c|c|c|c|c|c|c|c|}
\hline \multicolumn{10}{|c|}{ Total Variance Explained } \\
\hline \multirow{2}{*}{ Component } & \multicolumn{3}{|c|}{ Initial Eigenvalues } & \multicolumn{3}{|c|}{ Extraction Sums of Squared Loadings } & \multicolumn{3}{|c|}{ Rotation Sums of Squared Loadings } \\
\hline & Total & $\%$ of Variance & Cumulative \% & Total & $\%$ of Variance & Cumulative $\%$ & Total & $\%$ of Variance & Cumulative $\%$ \\
\hline 1 & 7.240 & 30.167 & 30.167 & 7.240 & 30.167 & 30.167 & 5.500 & 22.919 & 22.919 \\
\hline 2 & 4.721 & 19.669 & 49.836 & 4.721 & 19.669 & 49.836 & 4.779 & 19.912 & 42.831 \\
\hline 3 & 3.294 & 13.725 & 63.561 & 3.294 & 13.725 & 63.561 & 4.328 & 18.032 & 60.863 \\
\hline 4 & 3.152 & 13.132 & 76.693 & 3.152 & 13.132 & 76.693 & 3.799 & 15.830 & 76.693 \\
\hline 5 & .853 & 3.556 & 80.249 & & & & & & \\
\hline 6 & .660 & 2.748 & 82.997 & & & & & & \\
\hline 7 & .558 & 2.324 & 85.321 & & & & & & \\
\hline 8 & .469 & 1.954 & 87.275 & & & & & & \\
\hline 9 & .445 & 1.855 & 89.130 & & & & & & \\
\hline 10 & .411 & 1.711 & 90.841 & & & & & & \\
\hline 11 & .358 & 1.494 & 92.334 & & & & & & \\
\hline 12 & .345 & 1.439 & 93.773 & & & & & & \\
\hline 13 & .288 & 1.200 & 94.973 & & & & & & \\
\hline 14 & .225 & .939 & 95.912 & & & & & & \\
\hline 15 & .199 & .828 & 96.740 & & & & & & \\
\hline 16 & .143 & .597 & 97.337 & & & & & & \\
\hline 17 & .137 & .572 & 97.909 & & & & & & \\
\hline 18 & .117 & .488 & 98.397 & & & & & & \\
\hline 19 & .101 & .420 & 98.817 & & & & & & \\
\hline 20 & .087 & .364 & 99.182 & & & & & & \\
\hline 21 & .071 & .297 & 99.478 & & & & & & \\
\hline 22 & .053 & .222 & 99.701 & & & & & & \\
\hline 23 & .048 & .199 & 99.899 & & & & & & \\
\hline 24 & .024 & .101 & 100.000 & & & & & & \\
\hline
\end{tabular}

Source: Analysis results from the author's research data 
In the above analysis results table, the total variance extracted with the cumulative variance value of the factors is $76.693 \%>$ $50 \%$ meeting the standard. The author uses a rotation matrix:

Table 8

Rotated Factor Matrix

\begin{tabular}{|c|c|c|c|c|}
\hline & \multicolumn{4}{|c|}{ Component } \\
\hline & 1 & 2 & 3 & 4 \\
\hline DN2 & .912 & & & \\
\hline DN7 & .896 & & & \\
\hline DN4 & .891 & & & \\
\hline DN1 & .873 & & & \\
\hline DN5 & .860 & & & \\
\hline DN3 & .830 & & & \\
\hline DN6 & .821 & & & \\
\hline VM6 & & .932 & & \\
\hline VM1 & & .908 & & \\
\hline VM2 & & .908 & & \\
\hline VM5 & & .879 & & \\
\hline VM4 & & .863 & & \\
\hline VM3 & & .774 & & \\
\hline BT10 & & & .958 & \\
\hline BT11 & & & .879 & \\
\hline ВТ9 & & & .866 & \\
\hline BT8 & & & .848 & \\
\hline BT6 & & & .787 & \\
\hline BT7 & & & .635 & \\
\hline BT5 & & & & .938 \\
\hline BT2 & & & & .930 \\
\hline BT1 & & & & .843 \\
\hline BT4 & & & & .807 \\
\hline BT3 & & & & .796 \\
\hline
\end{tabular}

Source: Analysis results from the author's research data

The results show that there are four groups of factors drawn, including:

The first group of factors is named as the group of factors inside the enterprise (DN) with 7 items named DN1 to DN7.

The second group of factors is named as macro-environment factors (VM), named as VM1 to VM6.

The third group of factors is named as knowledge of business leaders (KT) which is made up of 5 items named BT1 to BT5.

The fourth group of factors is named as a group of factors belonging to family tradition and skills of business leaders (KN) formed from 6 items including BT6 to BT11.

Next, we analyze the influence of factors on the management capacity of business leaders. To perform the analysis, first, we perform the EFA analysis for the dependent variable which is the management capacity of business leaders. The conformity test of the research model using KMO and Bartlett's test are performed and the specific results are as follows:

Table 9

The results of KMO and Bartlett's Test Kaiser-Meyer-Olkin Measure of Sampling Adequacy. Bartlett's Test of Sphericity

Approx. Chi-Square

Df

Sig.

\section{.606}

161.383

6

.000

Source: Analysis results from the author's research data

KMO and Bartlett's scale (Kaiser-Meyer-Olkin) with value $=0.606$ satisfies a condition that ranges from 0.5 to 1. Factor analysis is consistent with real data. The results of Table 9 show that the Bartlett's Test results have a Sig value. $=0.000<0.05$, The observed variables are correlated with each other in the factor group, then perform testing the variance extracted of factors of the factors. 
Testing the variance extracted of factors

\begin{tabular}{|c|c|c|c|c|c|c|}
\hline \multirow[b]{2}{*}{ Component } & \multicolumn{2}{|c|}{ Initial Eigenvalues } & \multicolumn{4}{|c|}{ Extraction Sums of Squared Loadings } \\
\hline & Total & $\%$ of Variance & Cumulative \% & Total & $\%$ of Variance & Cumulative $\%$ \\
\hline 1 & 1.700 & 42.506 & 42.506 & 1.700 & 42.506 & 42.506 \\
\hline 2 & 1.013 & 25.336 & 67.842 & & & \\
\hline 3 & .729 & 18.214 & 86.056 & & & \\
\hline 4 & .558 & 13.944 & 100.000 & & & \\
\hline
\end{tabular}

Source: Analysis results from the author's research data

According to Table 10, the total variance extracted with the cumulative variance value of the factors is $42.506 \%$, which means $42.506 \%$ change of factors is explained by observed variables.

Table 11

Rotated Factor Matrix

\begin{tabular}{ll}
\hline NLQL1 & .810 \\
NLQL2 & .749 \\
NLQL3 & .587 \\
NLQL4 & .373 \\
\hline
\end{tabular}

Source: Analysis results from the author's research data

A group of factors is created and signified by NLQL to be named as the management capability factor of business leaders. Then, the author analyzes the influence of factors on the management capacity of the small and medium-sized enterprise director according to management function. The study used multivariate regressions to examine the impact of independent variables on the dependent variable, which:

+ Dependent variable: Management capacity of business leaders (NLQL)

+ Independent variable:

DN: Factors inside the enterprise

VM: Macro environment factors

KT: Factors of knowledge of business leaders

KN: Traditional family factors and leadership skills of business leaders

The author verifies the suitability of the data with the expected research model: With the Adjusted R Square coefficient $=0.553$, which indicates that about $55.3 \%$ of the variation of the dependent variable is explained by the independent variables in the model. Sig. coefficient $=0.000$ indicates an appropriate research model, the independent variables are linearly correlated with the dependent variables in the model.

Table 12

The results of regression analysis

\begin{tabular}{|c|c|c|c|c|}
\hline \multirow{2}{*}{\multicolumn{2}{|c|}{ Model }} & \multirow{2}{*}{$\begin{array}{c}\text { Standardized Coefficients } \\
\text { Beta } \\
\end{array}$} & \multirow{2}{*}{$\mathrm{t}$} & \multirow{2}{*}{ Sig. } \\
\hline & & & & \\
\hline \multirow{5}{*}{1} & (Constant) & & .000 & 1.000 \\
\hline & $\mathrm{DN}$ & .396 & 12.633 & .000 \\
\hline & VM & .408 & 13.027 & .000 \\
\hline & $\mathrm{KN}$ & .261 & 8.318 & .000 \\
\hline & KT & .407 & 12.983 & .000 \\
\hline
\end{tabular}

Source: Analysis results from the author's research data

As we can observe from the results of Table 12, there are two factors; namely the macro-environmental and the knowledge factors of business leaders which have the strongest influence on the management capacity of enterprises and the coefficient Standardized Coefficients are 0.408 and 0.407 respectively. The results are consistent with the previous views. Business leaders should continue to supplement and update their business knowledge and expertise, to meet the increasing requirements of their jobs, especially in the context of international economic integration. Business leaders also need to supplement and perform more training on their business management skills, create motivation to promote human resources in the enterprise and ensure that the company's resources always strive and devote their best to the enterprise. Enterprises need to have developed strategies following local development orientations and planning, taking the advantage of the local support for their development. 


\section{References}

Alzgool, M. (2019). Nexus between green HRM and green management towards fostering green values. Management Science Letters, 9(12), 2073-2082.

Barringer, B. R., \& Jones, F. F. (2004). Achieving rapid growth: revisiting the managerial capacity problem. Journal of Developmental Entrepreneurship, 9(1), 73.

Barringer, B. R., Jones, F. F., \& Neubaum, D. O. (2005). A quantitative content analysis of the characteristics of rapid-growth firms and their founders. Journal of Business Venturing, 20(5), 663-687.

Cohen, W. M., \& Levinthal, D. A. (2000). Absorptive capacity: A new perspective on learning and innovation. Strategic Learning in a Knowledge Economy.

Hair, Jr., J. F., Black, W. C., Babin, B. J., Anderson, R. E., \& Tatham, R. L. (2006). Multivariate Data Analysis, $6^{\text {th }}$ ed. Upper Saddle River, NJ: Pearson Prentice Hall.

Hair, J. F., Ringle, C. M., \& Sarstedt, M. (2011). PLS-SEM: Indeed a silver bullet. Journal of Marketing theory and Practice, 19(2), 139-152.

Khuong, M., Mai, T., \& Phuong, N. (2020). The impacts of human resource management practices on employees' motivation and loyalty. Management Science Letters, 10(11), 2673-2682.

Mintzberg, H. (1973), The Nature of Managerial work, New york: Harper \& Row.

Mintzberg, H. (2009). Managing. Berrett-Koehler Publishers, ISBN 9781605095325.

Mira, M., Choong, Y., \& Thim, C. (2019). Mediating role of port supply chain integration between involvement of human resource practices and port performance in Kingdom of Saudi Arabia. Uncertain Supply Chain Management, 7(3), 507-516.

de Oliveira, J., Escrivão, E., Nagano, M. S., Ferraudo, A. S., \& Rosim, D. (2015). What do small business owner-managers do? A managerial work perspective. Journal of Global Entrepreneurship Research, 5(1), 19.

Pham, H. (2020). Impact of human resource management practices on enterprises' competitive advantages and business performance: Evidence from telecommunication industry. Management Science Letters, 10(4), 721-732.

Tabachnick, B. G., \& Fidell, L. S. (1996). Using multivariate statistics. Northridge. Cal.: Harper Collins.

Vuong, B., \& Sid, S. (2020). The impact of human resource management practices on employee engagement and moderating role of gender and marital status: An evidence from the Vietnamese banking industry. Management Science Letters, 10(7), 1633-1648.

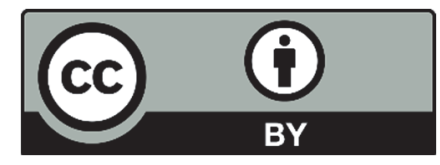

(C) 2020 by the authors; licensee Growing Science, Canada. This is an open access article distributed under the terms and conditions of the Creative Commons Attribution (CC-BY) license (http://creativecommons.org/licenses/by/4.0/). 